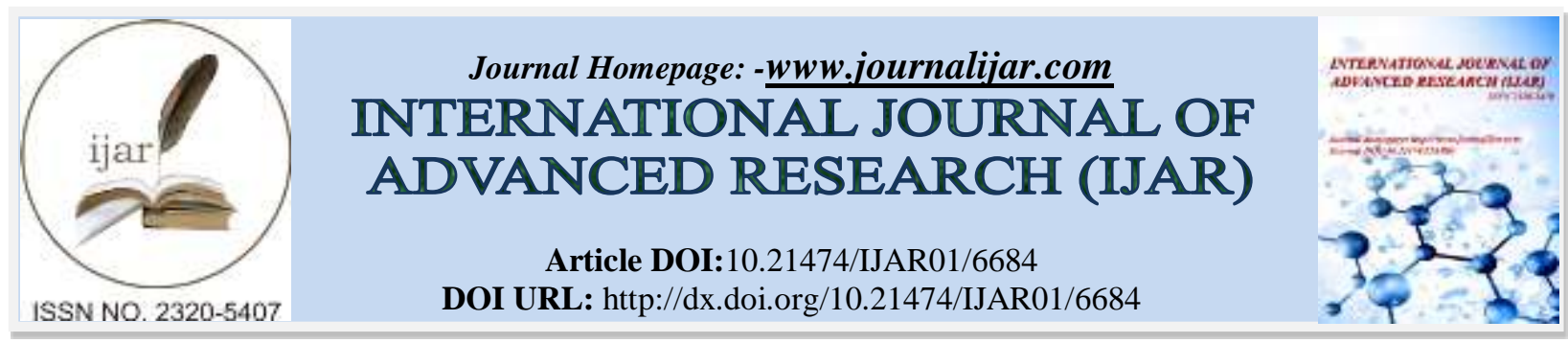

RESEARCH ARTICLE

\title{
LEAD (PB) CONTAMINATION IN STREET VENDORS FRIED FOODS IN SCHOOL AREA OF PADANG MUNICIPALITY, INDONESIA.
}

Taufiq Ihsan, Tivany Edwin and Elsa Fitriani.

1. Department of Environmental Engineering Faculty of Engineering Andalas University.

2. Kampus Limau Manis, Padang West Sumatra 25163 INDONESIA.

\section{Manuscript Info}

Manuscript History

Received: 06 January 2018

Final Accepted: 08 February 2018

Published: March 2018

Keywords:-

Fried Street Foods, Transportation, Padang, Hygiene And Food Sanitation, Lead $(\mathrm{Pb})$

\begin{abstract}
This study aimed to analyze the effect of transportation on lead $(\mathrm{Pb})$ concentration in fried street foods of Padang school area and to analyze hygiene and sanitation handling against processed fried street foods ingredients. Samplings for the analysis of $\mathrm{Pb}$ concentration in fried street foods of school was conducted at the school area that located on the primary arterial road and the local secondary road in Simpang Haru District. Fried street food sampling and vehicle volume counting were conducted for 7 consecutive school days. In addition, the distribution of questionnaires to students and also to all traders of street food. The average $\mathrm{Pb}$ content of fried street food on primary arterial roads in the range of $0.249-0.288 \mathrm{ppm}$ and on local secondary roads ranging from $0.155-0.218 \mathrm{ppm}$. The content of $\mathrm{Pb}$ in the primary arterial road passes the quality standard set by National Agency of Drug and Food Control Indonesia $(0.25 \mathrm{ppm})$ and SNI $(0.2 \mathrm{ppm})$. While the $\mathrm{Pb}$ content of the schools in the local secondary road only passed the SNI quality standard. The levels of $\mathrm{Pb}$ in food and volume of vehicles passing through the primary arterial road has a correlation value of 0.714 , while on local secondary roads was 0.143 . Pb in foods was not only caused by motor vehicle pollutants but also treatment when handling. This can be seen from the number of street vendors who do a positive treatment on hygiene and food sanitation to fried street food only about $30-70$ $\%$.

Copy Right, IJAR, 2018,. All rights reserved.
\end{abstract}

\section{Introduction:-}

Data from Indonesian National Social-Economic Survey (2016) mentioned that almost half the people in Indonesia that are equal to $49 \%$ choose fried food. Other preferred snacks in Indonesia are noodles about $45 \%$. It also occurs in oil as a frying medium. Approximately 290 million tons of oil are consumed each year. The high demand for cooking oil can be a tangible proof of how big it is fried foods consumed by humans by layers of a society of all ages (Ketaren, 2008). Fried street food becomes an option mainly because the price is cheap, tasty, easy to obtain, also can provide energy intake between meals. But in fact, not many know about the safety of these fried street foods to be consumed. One aspect that can cause fried street food is less safe for health if consumed is the contaminant content in it such as microbiological, chemical and physical contamination. The position of selling places on the edge of the highway allows the absorption of heavy metals from motor vehicle fumes, such as lead (Pb) (Lester, 2009). Contamination media can be air, dust, and water (ATSDR, 2010). 
According to the Environmental Protection Agency (EPA), about 25\% of Pb remains in the engine and another 75\% will pollute the air as exhaust fumes. $\mathrm{Pb}$ emissions from exhaust gases will still cause air pollution wherever the vehicle is located. The steps taken after the burning are as follows: as much as $10 \%$ will pollute the location within a radius of less than $100 \mathrm{~m}, 5 \%$ will pollute the location within a radius of $20 \mathrm{~km}$, and another $35 \%$ carry the atmosphere in a considerable distance (Surani, 2002).

Children tend to have a higher risk of lead toxicity than adults because children have a susceptibility to lead toxicity early in life from embryonic to human birth (WHO, 2010). Effects caused by $\mathrm{Pb}$ poisoning based on $\mathrm{Pb}$ levels in the blood in children that can lead to learning disorders, headaches, anemia until death (ATSDR, 2010).

In West Sumatra Province of Indonesia, fried foods are in great demand. A wide variety of fried foods are sold both in stores and street vendors. It is also widely found in Padang as the capital city of West Sumatra. Simpang Haru District in Padang City as a case study location was a dense area of traffic because it connects many destinations in Padang so that the pollutant potential of motor vehicle burning is higher enough in this area. In addition, there are many schools located along the road along the Simpang Haru area. In Simpang Haru, there is a school area (elementary school and junior high school). In this area found many street vendors fried foods on the roadside.

Based on the description, it is necessary to conduct this study on the content of $\mathrm{Pb}$ in fried street foods sold by street vendors in important areas such as school areas that should be free from $\mathrm{Pb}$ contamination through oral. In addition to the behavior of street vendors fried foods that are not in accordance with hygiene and sanitation standards that should be applied to foods.

\section{Method:-}

In this study, the questionnaire was distributed. the first questionnaire to the students related to the street vendors fried foods are favored, then questionnaires to street vendors related to hygiene and sanitation of merchants to their foods and fried foods sampling done in the school area. Vehicle volume calculation is done on the primary arterial road and local road secondary of Simpang Haru District. The selection of sampling sites in different types of roads was conducted to determine the effect of transportation pollutant levels on $\mathrm{Pb}$ content on fried foods.

Schools used as a research site consists of two elementary schools and two junior high schools located on the primary and secondary arterial roads of Simpang Haru District.

The type of questionnaire for the determination of fried street foods places in schools given to students is a validating closed questionnaire. The sampling method used is probability sampling which means every element of the population has the same possibility to be chosen through systematic calculation. The determination of the number of questionnaires distributed was calculated using the stratified random sampling method because the samples were taken on the basis of the class strata and the determination of the number of samples was done statistically with the Slovin Formula. Students who are used as respondents in filling questionnaires are students who have been able to read, write and understand sentences of questions.

The type of questionnaire used to see the level of hygiene and sanitation of the street vendors given to all traders in all schools is a closed questionnaire that has contained the option with the Guttman Scale (yes or no choice) for all questions so as to obtain firm results on the questions given. The results of the questionnaire will be made as a percentage of positive attitudes that have been done by the street vendor who obtained from the scoring value of each type of question. In the case of scoring, the correct or positive answer to the question will be given a one and negative answers will be scored zero. After obtaining the sampling point in all schools, the fried foods sampling is done for 7 consecutive days on active school day simultaneously during student break time. The amount of fried foods taken in one day of sampling is one fried food in each location, so the total of fried foods samples used in this study amounted to 28 samples. This is done in order to obtain the average content of $\mathrm{Pb}$ to fried foods on the active day of school. In addition, a counter was used the calculation of the volume of motor vehicles passing the nearest road during the sampling. Then the fried food samples were then tested by spectrophotometry method using Atomic Absorption Spectrophotometric (AAS). 


\section{Results and Discussion:-}

After sampling for 7 days on active days of school then get the levels of daily $\mathrm{Pb}$ at fried street foods. The average of $\mathrm{Pb}$ content of fried foods on primary arterial roads and local secondary roads Simpang Haru District with a maximum limit of allowable $\mathrm{Pb}$ content in foods can be seen in Figure 1.

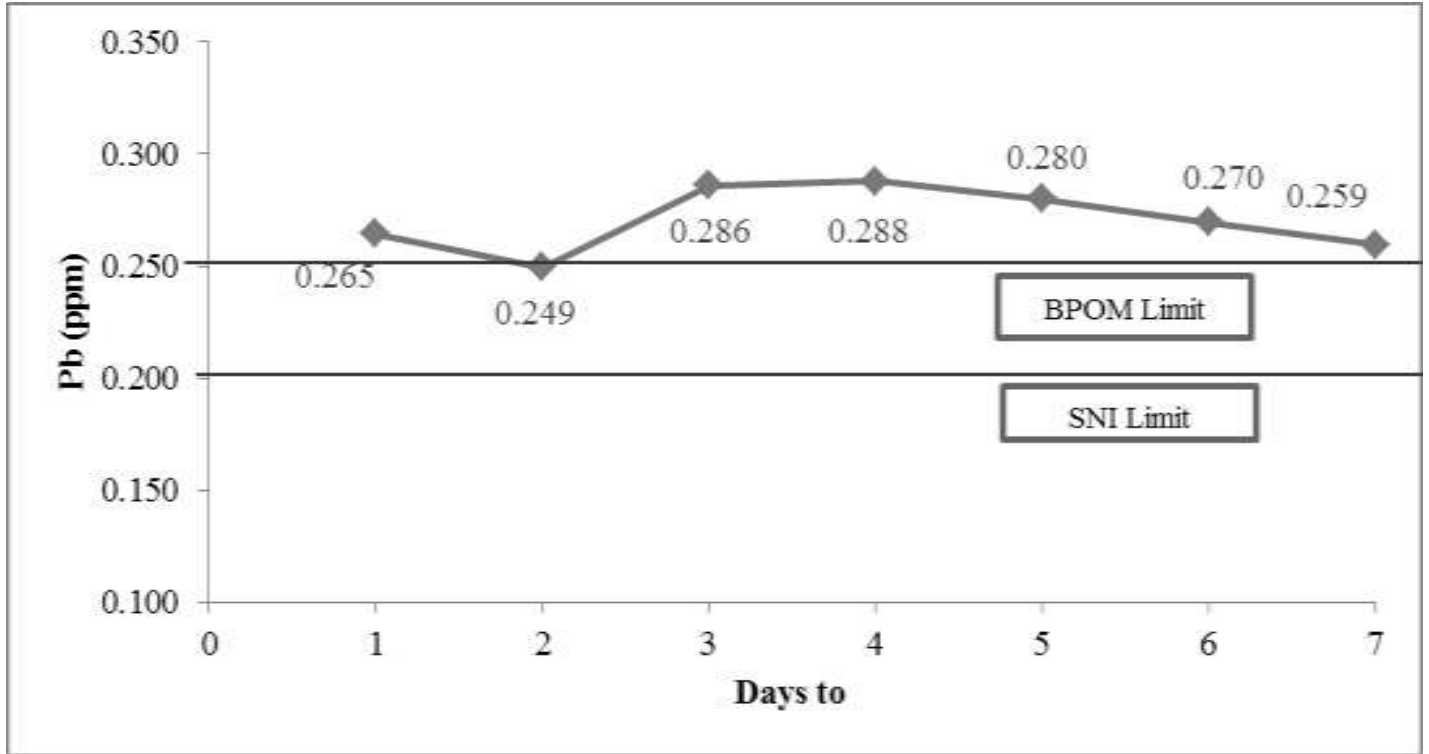

(a)

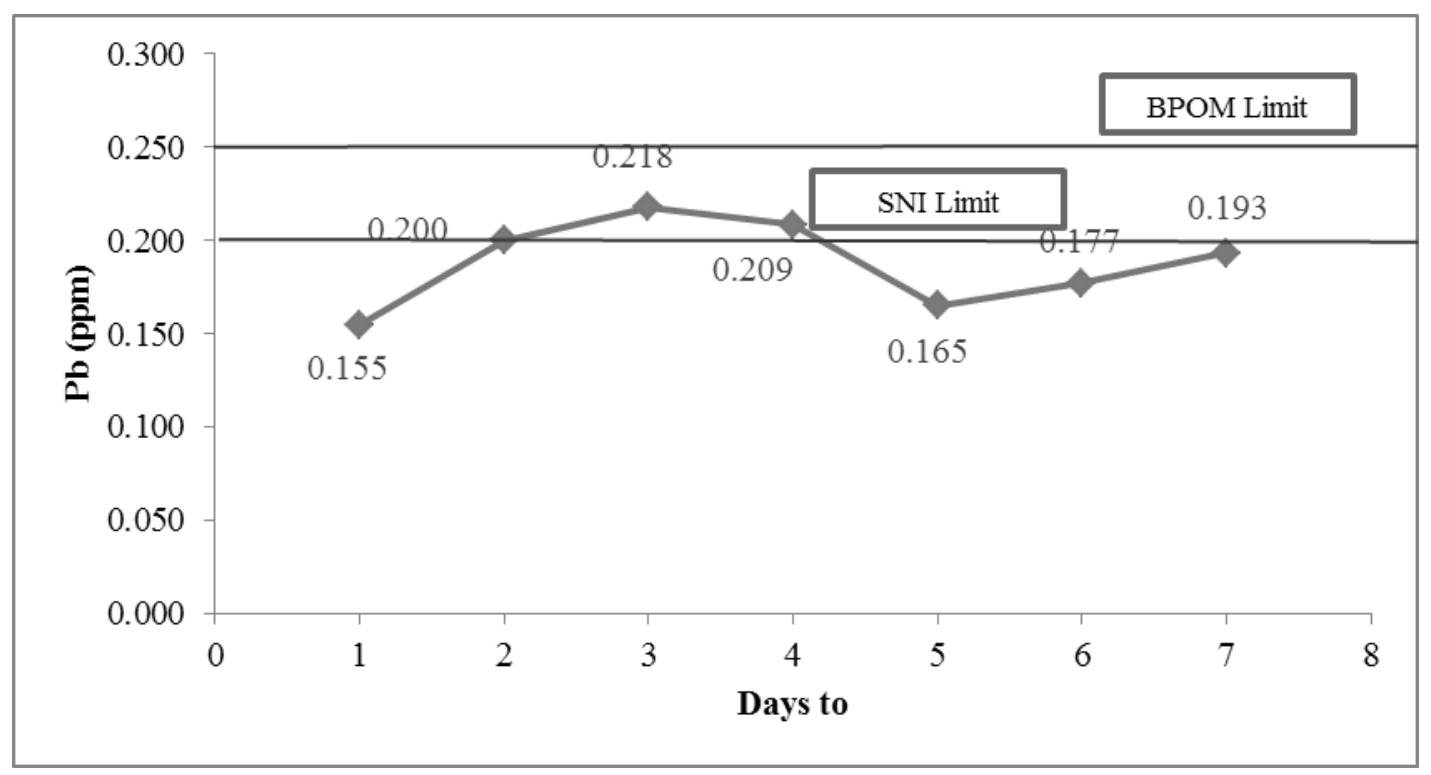

(b)

Figure 1:- (a) $\mathrm{Pb}$ Concentrations in Fried Foods on Primary Arterial Roads

(b) Pb Concentrations in Fried Foods on Local Secondary Roads

In Figure 1 it can be seen that $\mathrm{Pb}$ content in fried foods in primary arterial roads exceeds National Agency of Drug and Food Control Indonesia (BPOM) limit. While on local secondary roads, Pb content in fried foods, there are 2 days that exceed the SNI limit. The levels of $\mathrm{Pb}$ in fried foods compared with vehicle volume in each type of roads then got correlation by using SPSS Program as in Table 1. 
Table 1:- Relationship of Vehicle Volume with Pb Concentratons In Fried Foods

\begin{tabular}{|l|l|}
\hline Type of Roads & R-Value \\
\hline Primary Arterial & 0.714 \\
\hline Local Secondary & 0.143 \\
\hline
\end{tabular}

Table 1 shows the correlation between vehicles volume with $\mathrm{Pb}$ content on the fried foods that it affects. The relationship of $\mathrm{Pb}$ content to fried foods that are on the primary arterial road has a strong correlation $(\mathrm{r}=0.714)$. This indicates that if the vehicle volume increases, the levels of $\mathrm{Pb}$ in fried foods will also increase and vice versa. The correlation between vehicles volume passing through the local secondary road with the concentration of $\mathrm{Pb}$ on the fried foods influenced indicates a weak correlation $(\mathrm{r}=0.143)$. So it can be concluded that there are other factors that affect the levels of $\mathrm{Pb}$ in fried foods of school area at the sampling site away from the primary artery roads in Simpang Haru District.

In Reffiane's, et al (2011) proved that there is a tendency with increasing density of vehicle density, the level of $\mathrm{Pb}$ in the air also increases because the $\mathrm{Pb}$ content is accumulative, so the influence of $\mathrm{Pb}$ pollution on health is also increasing. $\mathrm{Pb}$ on food can be caused by equipment used in foods such as the use of tinned cans for side-grafting while packaging and the treatment of food handling ( $\mathrm{Lu}, 2006$; Palar, 2008). The levels of $\mathrm{Pb}$ that exceeds the standard of fried foods that will be consumed by children will be more harmful if compared to consume by adult (Tirima et al, 2017). Pb was higher absorption in small children than in adults (Guerin et al, 2017).

The content of $\mathrm{Pb}$ contained in the fried street foods not only comes from vehicle contamination (Surani, 2002; ATSDR, 2010). The result of sample measurement taken at street vendors fried foods of local secondary roads in Simpang Haru District, samples still contains $\mathrm{Pb}$ although its concentration is still allowed (but the concentration of $\mathrm{Pb}$ at the fried foods has been approaching the maximum limit determined by SNI) and not correlated with vehicles volume. In addition to measuring the levels of $\mathrm{Pb}$ contaminants in fried foods, the sanitation of fried foods sold in Simpang Haru District must also be considered because $\mathrm{Pb}$ contamination that occurs in fried foods can occur through the treatment of food. Before the division of questionnaires then tested the validity and reliability first and obtained the result that all questions on the questionnaire are valid. The distribution of questionnaires was done to all the street vendor fried foods who are located in the school area around in the primary artery roads and in the local secondary roads Simpang Haru District.

The attainment of merchant behavior can be said to be positive if the percentage achieved by the trader-related to sanitation behavior reaches good and excellent category that is in the large range of $60 \%$. In assessing the behavior of producers in handling fried foods, the high level of sanitation will produce foods that are more recommended for consumption because it will affect the level of consumer health. Sanitation to be considered include sanitation in the selection of foodstuffs, sanitation in food storage, sanitation while processing food, sanitation while storing cooked food, sanitation in food transport and sanitation while serving food (Minister of Public Health, 2003). Figure 2 is the number of traders who achieve a positive attitude related to sanitation conducted on fried street foods. 


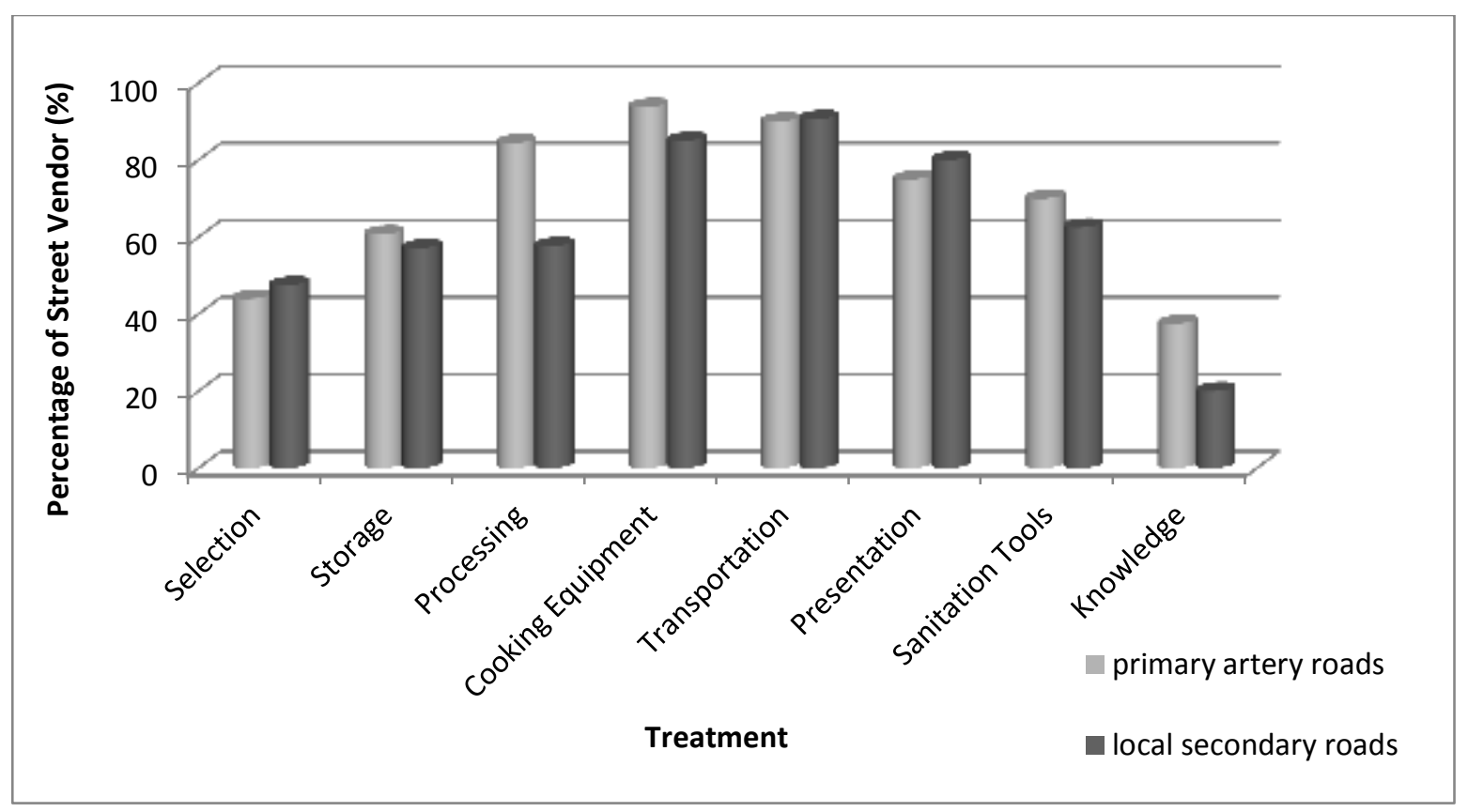

In Figure 2 it can be concluded that the hygiene and sanitation level of street vendor fried foods located on the primary arterial roads is better when compared with street vendor fried foods on the local secondary roads. It can be seen from the percentage level obtained in the type of hygiene and sanitation treatment on fried foods. In addition, the question related to the potential of $\mathrm{Pb}$ in the questionnaire obtained the result that the level of positive behavior of street vendors who fried in the primary arterial road better. In the treatment of traders on the factors that are at risk of $\mathrm{Pb}$ contamination in fried foods can be the cause of $\mathrm{Pb}$ concentration that is close to the limit of quality standard that has been established by SNI 7387-2009 about the maximum limit of heavy metal contamination in food on fried street foods sold at the location on the road local secondary. Positive behavior on hygiene and food sanitation will have an impact on foodborne diseases (Barjaktarović-Labović et al, 2017).

\section{Conclusion:-}

The average $\mathrm{Pb}$ content of fried street foods in the school area of Simpang Haru District in the primary arterial road is $0.2672 \mathrm{ppm}$ and $0.2791 \mathrm{ppm}$. In the school area Simpang Haru District in the local secondary road of $0.1851 \mathrm{ppm}$ and $0.1911 \mathrm{ppm}$. Pb concentration on fried street foods on the primary arterial road Simpang Haru District exceeds the maximum limit allowed in SNI $(0.2 \mathrm{ppm})$ and BPOM $(0.25 \mathrm{ppm})$. While Pb content in areas far from roads location on local secondary roads is still within the permitted safe limits. The content of $\mathrm{Pb}$ on fried street foods and volume of vehicles passing through the primary arterial road has a correlation value of 0.714 , while the $\mathrm{Pb}$ content of local secondary roads I 0.143 . The levels of $\mathrm{Pb}$ in fried foods is not only caused by vehicle pollutants but also treatment when handling. This can be seen from the number of the street vendor who are on the local roads only 30 $-50 \%$ and the street vendor who are on the primary arterial road do a positive treatment about $70 \%$.

\section{Acknowledgements:-}

This research was conducted under financial support from PNBP funding 2018 of Faculty of Engineering, Andalas University, Padang, Indonesia. 


\section{References:-}

1. Agency for Toxic Substance and Desease Registry (ATSDR). 2010. Case Studies in Evironmental Medicine: Lead Toxicity. USA: Agency for Toxic Substance and Desease Registry.

2. Barjaktarović-Labović, S., Mugoša, B., Andrejević, V., Banjari, I., Jovićević, L., Djurović, D., Martinović, A., Radojlović, J. 2018. Food hygiene awareness and practices before and after intervention in food services in Montenegro. Food Control. doi: 10.1016/j.foodcont.2017.10.032

3. Guérin, T., Le Calvez, E., Zinck, J., Bemrah, N., Sirot, V., Leblanc, J.C., Chekri, R., Hulin, M., Noël, L. 2017. Levels of lead in foods from the first French total diet study on infants and toddlers. Food Chemsitry, 237: 849 $-856$.

4. Indonesian National Standard (SNI) No. 7387:2009 about Maximum Limit of Heavy Metal Contamination in Foods. 2009

5. Indonesian National Social-Economic Survey. 2016. 2015 Module Data Sheet.

6. Ketaren, S. 2008. Oil and Fat of Foods Technology. Jakarta: UI-Press (in Bahasa Indonesia).

7. Lester, D. 2009. Environmental Toxicants; Human Exposures and Their Health Effects. USA: John Willey \& Sons, Inc.

8. Lu, F. C. 2006. Basic Toxicology-Indonesian Edition. Jakarta: UI- Press.

9. Minister of Public Health Regulation NO.942/MENKES/SK/VII/2003 about Rules of Hygiene and Food Sanitation.

10. National Agency of Drug and Food Control Indonesia (BPOM RI). 2009. Head of National Agency of Drug and Food Control Indonesia Regulation No HK.00.06.1.52.4011 about Limits Microbe and Chemical Contamination in Foods. Jakarta: National Agency of Drug and Food Control Indonesia (in Bahasa Indonesia).

11. Palar, H. 2008. Toxicology of Heavy Metal. Jakarta: Reneka Cipta (in Bahasa Indonesia)

12. Reffiane, F., Mohammad N. A., Santoso, B. 2011. Effects of Leads (Pb) to Students Intelligence of Elemntary School. MALIH PEDDAS 1(2): 96-107 (in Bahasa Indonesia)

13. Surani, R. 2002. Environmental Health. Jakarta: Gadjah Mada University Press (in Bahasa Indonesia)

14. Tirima, S., Bartrem, C., von Lindern, I., von Braun, M., Lind, D., Anka, S. M., Abdullahi, A. 2017. Food contamination as a pathway for lead exposure in children during the 2010-2013 lead poisoning epidemic in Zamfara, Nigeria. J. Environ. Sci. (2017), http://dx.doi.org/10.1016/j.jes.2017.09.007 